\title{
IAMJ
}

INTERNATIONAL

AYURVEDIC

MEDICAL JOURNAL

$\underline{\text { Review Article }}$

ISSN: 23205091

Impact Factor: 5.344

\section{A DETAILED ANALYSIS OF THE GYNAECOLOGICAL DISEASES BASED ON CHATURVIDHA GARBHOTAPATTI SAMAGRI: A REVIEW}

\section{Divyarani}

Associate Professor, Dept. Samhita Siddhanta,

Yenepoya Ayurveda Medical College, Naringana, Mangalore, Karnataka, India

Email: divya.hpatil@gmail.com

\section{https://doi.org/10.46607/iamj1808082020}

(Published online: August 2020)

Open Access

(C) International Ayurvedic Medical Journal, India 2020

Article Received: 08/07/2020 - Peer Reviewed: 29/07/2020 - Accepted for Publication: 01/08/2020

D) Check for updates

\begin{abstract}
Women perpetuate the human race by creating and mothering children. The health of the family and society that revolves around women depends to a large degree on her health. But some of the physiological phenomenon's deranged trouble the lady to make her slow down the race, problems include various menstrual disorders. Incidences of gynecological disorders have increased alarmingly. Ayurveda is one of the most ancient healthcare systems in the world. At present time, the existence of everything has been proved practically and scientifically. It is the time for Ayurveda to evolve itself through scientific validation. In Ayurveda, the matter related to the concepts of Garbha (Uterus), Garbhotpatti Samagri (factors responsible for formation of womb), and Striroga (Gynecological Disorders) are described systematically. Ayurveda classics have explained four important factors as Garbha Sambhava Samagri that is Ritu (Menstrual Period), Kshetra (field), Ambu (water) and Beeja (seed). These factors are very essential for conception. Also, Samhithas have explained all gynecological disorders under one heading of Yoni Vyapad (Gynecological Disorders). So, for proper understanding of gynecological diseases in Ayurveda a thorough understanding of Garbhotapatti Samagri helps to analyze suitable conditions for conception and healthy development of fetus. This study will help us to know the diseases related to Ritu, Kshetra, Ambu and Beeja.
\end{abstract}

Keywords: Garbha, Garbhotpattisamagri, Striroga, Ritu, Kshetra, Ambu, Beeja 


\section{INTRODUCTION}

Garbha is the first stage of development of Sharira (body). The union of Shukra (sperm) and Shonita (ovum) along with Atma (soul) in the Garbhashaya (uterus) is known as Garbha (embryo).

It is formed as a result of combination of Ashtaprakrutis (8 prakrutis) and Shodashavikaras (16 vikaras). On the other hand, the combination of Shukra, Shonita and Jeeva (soul) inside the Kukshi (uterus) is known as Garbha ${ }^{2}$ According to Sushruta Samhitha, Garbha is the result of combination of four factors coming together in the proper way, just like Ritu (season), Kshetra (Field), Ambu (water) and Beeja (seed) coming together to give rise to the $A_{n k u r}{ }^{3}$ (sprout).

Ritu: Ritu means menstruation in females ${ }^{4}$ which is of twelve days duration when Artava (Menstrual blood) is visible but some Aacharyas say there is a period of invisible Artava also. In female's menstruation starts around twelve years of age and ceases at the age of fifty years ${ }^{5}$. The period from first day of menstruation till twelfth day of menstruation is termed as Ritukaala. According to Bhavaprakasha, period from first day of menstruation till sixteenth day is called Ritukaala. The period in which ovulation occurs and this period are suitable for conception of Garbha ${ }^{6}$. This is valid scientifically too where the ovulation occurs on the 14th day in a 28 -days cycle and ranges between 12th to 16th day of menstruation.

The gynecological diseases that affect the Ritu are Sasrija/ Raktayoni, Pittaja yonivyapad and Rakta pradara or Asrigdara. Due to Dirana (excessive secretion) of Asrik (menstrual blood) in this disease, it is known as Asrigdara ${ }^{7}$. Asrigdara is also called Raktapradara due to Pradirana (excessive excretion) of $R^{2} a^{8}$ (menstrual blood). The Vayu after getting vitiated, increases quantity of Rakta (blood), takes Rakta to Rajovahasiras and increases the quantity of rajah that comes out through Rajovahasiras and causes Raktapradara.

Kshetra: The term Kshetra indicates the Garbhashaya (uterus). It is also called Kukshi. It is the eighth Ashaya which is present especially in females ${ }^{10}$. The word Garbhashaya is derived by the combination of two words i.e. Garbha and Ashaya. Ashaya means the place or special site for specific Dravya (material) of the body. Thus, the Garbhashaya means the special place where Garbha lies and develops ${ }^{11}$. Yoni resembles the $A a-$ varta (spirals) of the Shankha (conch shell) and having three Aavarta. The Garbhashaya lies in the third Aavarta of Yoni. Kukshi (uterus) provides a space for development of Garbha and also protects the Garbha from external pressure or trauma. Inside the uterus, the Garbha lives the intrauterine life of 9 months. The Shuddha Garbhashaya (normal uterus) is very essential for safe conception and development of foetus also. Any abnormality related to uterus gives rise to infertility. If any diseases in uterus, the power of implantation will be $\operatorname{lost}^{12}$. Similarly, Yoni Vyapad (diseases of vagina) also interferes the conception ${ }^{13}$. So, the Yoni Vyapad that affects the Kshetra are Vataja Yonivyapad, Kaphaja Yonivyapad, Acharana, Aticharana, Prakcharana, Antarmukhi, Suchimukhi, Mahayoni, Prasramsini, Phalini, Karnika, Paripluta, Vipluta, Shushka and Upapluta.

Ambu: The term Ambu represents Rasa Dhatu (nutritional elements) which is formed after complete digestion of Ahara $^{14}$ (food). The main function of Rasa dhatu is Prinana which means nourishment. According to Ayurveda, the Aahara rasa (essence of food) formed after the digestion of food consumed by mother is divided into three parts. First part nourishes her body, second promotes the formation of milk and third nourishes the Garbha. Nabhinadi of Garbha is attached with Rasavaha nadi of mother which carries Veerya (essence) of Aahar rasa (nutritious parts) from mother to the foetus by Upasneha (Indirect Nutrition or diffusion) for development of foetus. The Garbha is completely dependent on the mother's nutritional status for nourishment. If there is any improper diet taken by mother, it may directly affect the Garbha and may end up in various Garbhaj vikritti (foetal anomaly) such as Garbhasrava (abortion), Mritagarbha, Upavistaka, Nagodara etc. If the Garbha 
does not get nourishment, then it consequently gets Shosha (dried up) or miscarriage.

So, the Yoni Vyapad that affects the Ambu is Lohitakshaya and Arajaska Yonivyapad. Also, since Stanya is the Upadhatu of Rasa Dhatu affects the Ambu, hence Stanya Dustiroga can be considered as the vitiated Doshas moving through Kshiravaha Siras vitiate the milk and produce eight types of milk disorders.

Beeja: Beeja denotes the Shukra (sperm) of men and Artava (ovum) of women ${ }^{15}$. The qualities of pure Sukra and Aartava and qualities of vitiated Sukra and Aartava by Vata, Pitta, Kapha are described in detail. Now a day's different factors are affecting the Beeja, so many Beejadosha are coming up. Ayurvedic texts have very systemic description about the concept of Garbha Sambhav Samagri. In this concept, Ritu, Kshetra, Ambu and Beeja are referring to ovulatory phase, healthy uterus, proper nourishment and unvitiated semen of male and unvitiated ovum of female respectively. These are very essential for conception and ultimately the better offspring. All the factors responsible for infertility described in modern science can be included under these four factors. Developmental anomalies of foetus are also possible due to the abnormalities in these factors. So, the concept of Garbha Sambhav Samagri is described to bring healthy offspring into the society.

Artava: Artava (menstrual blood) which resembles the blood of a Shasha (rabbit) or Laksha rasa (liquid essence of lac) and that which does not stain the cloth is greatly praised. Same the pure (normal) $\mathrm{Ar}$ tava should be similar to colour of Gunja seed (Abrus precatorius), red lotus flower, lac juice and Indragopaka ${ }^{16}$ (red insect). Artava is vitiated by Tridoshas and Shonita (blood) each separately, by their combination in two or all together, becomes incapable of producing offspring. The diseases that affect Artava are Udavartini, Putraghni, Shandhi, Arajska, Vamini, Vandhya, Atyananda and Sasrija/raktayoni.

Table 1: Classification of gynecological disorders based on Garbhotapatti Samagri

\begin{tabular}{|c|c|c|c|c|}
\hline Si. No & Ritu & Kshetra & Ambu & Beeja/Artava \\
\hline 1 & Vataja Pradara & Vataja yonivyapad & Virasata Stanyadusti & Udavartini \\
\hline 2 & Pittaja Pradara & Aticharana & Phenayukta Stanyadusti & Putraghni \\
\hline 3 & Kaphaja Pradara & Acharana & Rukshata Stanyadusti & Shandhi \\
\hline 4 & Sannipataja Pradara & Prakcharana & Vivarnata Stanyadusti & Arajaska \\
\hline 5 & Sasrija/ Raktayoni & Antarmukhi & Durgandhata Stanyadusti & Vamini \\
\hline 6 & Pittaja yonivyapad & Suchimukhi & Snehayukta Stanyadusti & Vandhya \\
\hline 7 & - & Mahayoni & Picchila Stanyadusti & - \\
\hline 8 & - & Prasramsini & Guru Stanyadusti & - \\
\hline 9 & - & Phalini & - & - \\
\hline 10 & - & Karnika & - & - \\
\hline 11 & - & Paripluta & - & - \\
\hline 12 & - & Vipluta & - & - \\
\hline 13 & - & Shushka & - & - \\
\hline 14 & - & Upapluta & & - \\
\hline
\end{tabular}

\section{DISCUSSION}

There are different forms of Gynecological disorders existing throughout the history from which a woman faces so many problems in her reproductive life. For conception and fertility, Ayurveda explained Garbhotapatti Samagri i.e. Ritu, Kshetra, Ambu and Bija should be devoid of Dosha, not having any deformity or damage. So, understanding diseases that affects Garbhotapatti Samagri is necessary to prevent the diseases and maintain healthy state in order to conceive and get a healthy progeny. 
RITU - Ritu means menstruation period of females, Garbhagrahana Yogya Kala and it is the proliferative phase ending with ovulation. So, disease affects Ritu is mainly Pradara or Asrigdara. Raktapradara is with specific symptomatology like excessive amount and duration of bleeding, intermenstrual bleeding. Normal menstrual bleeding is cyclic, 3-5 days durations and 50-60 ml with its normal color as described in Ayurvedic classics. But when normal menstrual bleeding pattern is altered in reference of duration, amount, colour and cycle, the conditions are called $\mathrm{Ar}$ tavadushti and Menorrhagia is being one of them. Acharya Charaka says that excessive vaginal bleeding during menstruation is the only symptom of Asrigda$r a^{17}$. According to Sushruta Samhita, there are body ache and pain symptoms present in all types of Asrigdara with excessive vaginal bleeding ${ }^{18}$. Dalhana says in his commentary on Sushruta Samhita that burning sensation in lower portion of groin, pelvic region, back, renal region and flanks and severe pain in uterus as symptoms present in Asrigdara ${ }^{19}$. Vriddha Vagbhata has described excessive bleeding during menstrual or intermenstrual period as symptom of Asrigdara $^{20}$. Also, in Pittaja Yonivyapad, Raktayoni, Rudhirkashara, Apraja etc. Atiraktasrava is the main symptom. It can be correlated with ovulatory or nonovulatory Dysfunctional uterine bleeding. Among Ashta-artavadushti, Raktajaartava-dushti menorrhagia is also found as prominent symptom. The Asrigda$r a$ can be correlated to Menorrhagia as per modern on the basis of different signs $\&$ symptoms. Features like Varna (colour) and Vedana (pain) of such vitiated $\mathrm{Ar}$ tava should be recognized according to Dosha.

KSHETRA - The term Kshetra indicates the Garbhashaya (uterus). So here we have to consider Structural deformity or pain in the uterus or vaginal area.

Vataja Yonivyapad - Toda (Pricking type pain), Vedana (Pain), Stambha (Stiffness), Pipilika sruptimiti (Numbness), Karkashata (Roughness), Supti (loss of sensation), Yonibhramsha (Genital prolapse), Vankshana-parshwa vyatha (pain in back, groin region). Aticharana- Sopha (inflammation), Supti (Numbness), Ruja (pain), does not retain the Bija. While comment- ing Dalhana quotes that woman does not achieve conception and can be correlated with Vaginitis.

Acharana- Kandu (itching), Atinarakankshini, Jantu in Yoni. While commenting on this Dalhana has mentioned that in this disease the woman is hyper excited during coitus than the man or she feels excessive itching and therefore fertilization does not occur.

Prakcharana- Vedana in Kati, Prusta, Uru, Vankshana, Jangha. (Pain is main symptom in different parts).

Antarmukhi- Vakra Yoni Mukha, can be correlated to Retroversion and Retroflexion of uterus. In this condition there will be dyspareunia and low backache are common features.

Suchimukhi- Anudwara Yoni, Atisamvrutta, refers to narrowing of the vaginal canal and pinhole os of cervix both can be considered. Thus, it appears to be the description of congenital pinhole of cervix.

Mahayoni - Vistambha, Asamvrutta Yoni Mukha, Vivrutta, Srasta, Maharuja, Mamsautsanna in yoni. It can be correlated with Genital prolapse i.e. prolapse of the reproductive organs. The word Yoni refers to vaginal canal and uterus, thus prolapse of vaginal wall and uterus both can be considered.

Prasramsini - Kshobhana in Yoni. It can be correlated with Genital prolapse.

Phalini - When young woman has coitus with man having big penis then she suffers from the disease Phalini. While commenting on this Dalhana gives another name as Aphalini and says that woman remains infertile. In Madhukosha commentary and Bhava Prakasha it is mentioned that initial narrow Yoni protuberates like an egg, hence it is named as Andini. Karnika-Produces Karnika in Yoni. It appears to be a muscular structure covered with small spouts or knots, growing over cervix uteri. Thus, this condition resembles with all types of cervical polyps.

Paripluta - Shotha, Sparshaasahya, Shoola, Toda, Gramyadharme ruja. During coitus pain and burning sensation will be present in yoni.

Vipluta-Nityavedana in Yoni, constant pain in vagina. Shushka- Yonishosha, Atiruja in Yoni, dryness and severe pain in Yoni.

Upapluta- Toda in Yoni Pradesh. Constant pain will 
be present in Yoni.

$\boldsymbol{A M B U}$ - The term Ambu represents Rasa dhatu. Ambu cannot be compared with Stanya, but as it is the Upadhatu of Rasa Dhatu and also during pregnancy only some quantity of blood nourishes breast milk in pregnant lady. So Stanyadusti can be taken as disease that affects Ambu. Stanya will have role only after the birth of fetus but formation will take place during pregnancy itself. So, if Stanya is abnormal in color, smell, taste, touch and having other abnormal Gunas, it will be impure and cannot provide nourishment to the child. This Stanya may be called Dusta. It is necessary to identify the difference between Prakruta and Dustastanya. Rasa Dhatu is the ultimate outcome of food which possesses all following criteria.

From Raktadhatu: According to Kashyapa, after fertilization, some quantity of blood nourishes breast milk in pregnant lady.

From Raja: Even though Upadhatu cannot nourish other entity in the body, the Raja nourish Stanya, it may seem like Shastra Viruddha or Tantradosha. But virtually, the actual cause is the left-over Raja after formation of Garbha goes upward to Stana and there by the action of pitta, colour of Raja changes from red to pale white and transformed into Stanya. Chakrapa$n i$ commenting on this word told that Stanya exist only due to 'Avarodha of Raja'.

BEEJA - Beeja denotes the Shukra (sperm) of men and Artava (ovum) of women, gynecological diseases dealing with Artava related disorders affect Beeja. Udavartini -Rugarta Rajah Munchati, Rajah Kruchhrena Munchati, Saphenaartava munchati, Anila Vedana, Sakapha Artava munchati, Artavavimukte labhatesukham. While commenting Indu has added discharge of clotted blood. (Baddham Rajoraktam). The symptom, immediate relief of pain following discharge of menstrual blood 'has been explained in Charaka Samhita in the Context of Udavartini and this symptom is a characteristic feature of primary dysmenorrhea. It explains pain with colicky nature, onset at beginning of menstrual flow and last for few hours explains the typical character of pain in Primary Dysmenorrhea.

Putraghni- Garbham jatamjatam vinashayeta, Stitam- stitamhanti Garbhasrava. This condition can be correlated with recurrent abortions. In this condition repeated abortions takes place due to genetic factor, infections, anatomical abnormalities etc.

Shandhi - Anartava. It can be correlated with the Turner's syndrome, based on its cause and clinical features it is a congenital disorder characterized with amenorrhea, absence or very slight development of breasts.

Arajaska - Raktakshaya. In this condition along with amenorrhoea marked emaciation and fever etc. are also present; hence it appears to be secondary amenorrhea.

Vamini - Shadahat - Saptaratrashukrasrava. Some extent it can be correlated with very early abortion due to failure of implantation.

Vandhya- Nastartava, Niraratava. In Sushruta Samhita it is mentioned under Vataja Yonivyapad. According to description of Acharya Charaka and Acharya Vagbhata, while describing Bijamsadusti (chromosomal/genetic abnormalities) have been mentioned that if part of Bija responsible for the development of uterus is defective then born child would be Vandhya. Chakrapani has included abnormalities of the part of Bija responsible for development of Artava and Garbhashaya both. Hence by the description of Brihatrayi's, Vandhya Yonivyapad can be correlated with primary amenorrhea due to congenital absence or marked abnormalities of uterus as well as ovaries.

Atyananda -Na santosham gramyadharmena. Woman feels excessive sexual desire and does not get satisfied with coitus and produce unctuousness and itching.

\section{CONCLUSION}

Ayurvedic texts have very systematic description about the concept of Garbha Sambhava Samagri and Strirogas. In this concept, Ritu, Kshetra, Ambu and Beeja are referring to ovulatory phase, healthy uterus, proper nourishment and unvitiated semen of male and unvitiated ovum of female respectively. So, understanding all the gynecological diseases that affects these four Samagri and preventing these diseases are very essential for conception and ultimately the better offspring. All the factors responsible for infertility 
described in modern science can be included under these four factors. Developmental anomalies of fetus are also possible due to the abnormalities in these factors. So, the diseases and the symptoms that vitiate Garbha Sambhava Samagri are described to bring healthy offspring into the society.

\section{REFERENCES}

1. Srikanthamurthy K. R., Sushrut Samhita vol-1, edition 2004, Chaukhamba Orientalia Varanasi, Sharirsthan, Chapter 5, Verse 3, Page 78

2. Sharma Priyavrat, Charak Samhita vol-1, edition 2014, Chaukhamba orientalia Varanasi Sharirsthan, Chapter 4, Verse 5, Page 428

3. Srikanthamurthy K. R., Sushrut Samhita vol-1, edition 2004, Chaukhamba orientalia Varanasi, Sharirsthan, Chapter 2, Verse 33, Page 26

4. Thakral Kewal Krishna, Sushrut Samhita Dalhana teeka, Part-2, 1st edition 2014, Chaukhamba Orientalia Varanasi, Sharirsthan, Chapter 2, Verse 33, Page 31

5. Srikanthamurthy K. R., Sushrut samhita vol-1, edition 2004, Chaukhamba orientalia Varanasi, Sharirsthan, Chapter 3, Verse 6, Page 37

6. Mishra Brahmashankara, Bhavaprakash of Bhavamishra, 10th edition 2002, Chaukhamba sanskrit sansthan Varanasi, Purva khand, Chapter 3, Verse 2, Page 20

7. Achaya Charaka, Charak Samhita (Chikitsa sthana), Hindi Translation by Pandit Kashinath Nath Shastri and Dr Gorakh Nath Chaturvedi, Reprint, Varanasi, Chaukhambha Sanskrit Series, 1997, chapter 30, p. 777 .

8. Achaya Charaka, Charak Samhita (Chikitsa sthana), Hindi Translation by Pandit Kashinath Nath Shastri and Dr Gorakh Nath Chaturvedi, Reprint, Varanasi, Chaukhambha Sanskrit Series, 1997, chapter 30, p. 778.

9. Thakral Kewal Krishna, Sushrut samhita Dalhana teeka, Part-2, 1st edition 2014, Chaukhamba orientalia Varanasi, Sharirsthan, Chapter 2, Verse 33, Page 31

10. 10. Shastri Ambikadutta, Sushrut samhita part-1, Reprint 2007, Chukhamba Sanskrit sansthan Varanasi, Sharirsthan, Chapter 5, Verse 8, Page 42

11. Shastri Ambikadutta, Sushrut samhita part-1, Reprint 2007, Chukhamba Sanskrit sansthan Varanasi, Sharirsthan, Chapter 5, Verse 51, Page 48
12. Tripathi Brahmanand, Charak samhita, Reprint 2004, Chukhamba surbharati prakashan Varanasi, Sharirsthan, Chapter 2, Verse 6, Page 839

13. Shastri Kashinath, Charak samhita part-2, Reprint 2004, Chukhamba bharati academy Varanasi, Chikitsasthan, Chapter 30, Verse 38, Page 846

14. Thakral Kewal Krishna, Sushrut samhita Dalhana teeka, Part-2, 1st edition 2014, Chaukhamba orientalia Varanasi, Sharirsthan, Chapter 2, Verse 33, Page 31

15. Thakral Kewal Krishna, Sushrut samhita Dalhana teeka, Part-2, 1st edition 2014, Chaukhamba, orientalia Varanasi, Sharirsthan, Chapter 2, Verse 33, Page 31

16. Sharma Priyavrat, Charak samhita vol-2, edition 2014, Chaukhamba orientalia Varanasi, Chikitsasthan, Chapter 30, Verse 226, Page 523

17. Achaya Charaka, Charak Samhita (Chikitsa sthana), Hindi Translation by Pandit Kashinath Nath Shastri and Dr Gorakh Nath Chaturvedi, Reprint, Varanasi, Chaukhambha Sanskrit Series, 1997, p. 777.

18. Acharya Sushruta, Sushruta Samhita (Sharira Shana), Ayurveda Tatva Sandipika, Hindi commentary by Ambika Dutta Shastri, Chaukhambha Sanskrit Series, chapter 5, 2003, p.12.

19. Acharya Sushruta, Sushruta Samhita (Uttara Tantra), Ayurveda Tatva Sandipika, Hindi commentary by Ambika Dutta Shastri, Chaukhambha Sanskrit Series, 1998, chapter 38, p.310.

20. Acharya Vriddha Vagbhat, Astanga Samgrah (Sharira Shana), Indu Sanskrit Commentary by Vaidya Anant Damodar Athawale, Pune, 1980, chapter 1, p.262.

\section{Source of Support: Nil Conflict of Interest: None Declared}

How to cite this URL: Divyarani: A Detailed Analysis Of The Gynaecological Diseases Based On Chaturvidha Garbhotapatti Samagri: A Review. International Ayurvedic Medical Journal \{online\} 2020 \{cited August, 2020\} Available from: http://www.iamj.in/posts/images/upload/4151 4156.pdf 